\title{
Response mechanisms of Brachiaria brizantha cultivars to water deficit stress $^{1}$
}

\section{Patricia Menezes Santos², Pedro Gomes da Cruz², Leandro Coelho de Araujo², José Ricardo Macedo Pezzopane ${ }^{2}$, Cacilda Borges do Valle ${ }^{3}$, Cristiana de Gaspari Pezzopane ${ }^{2}$}

\author{
${ }^{1}$ Financial support from Fapesp. \\ 2 Embrapa Pecuária Sudeste, São Carlos, SP, Brasil. \\ ${ }^{3}$ Embrapa Gado de Corte, Campo Grande, MS, Brasil.
}

\begin{abstract}
Two cultivars of Brachiaria brizantha (Hochst ex. A. Rich) Stapf. (Syn. Urochloa) were evaluated for their adaptation to water deficit and the stress response mechanisms in a greenhouse experiment. The experimental design was in completely randomized blocks with a $2 \times 2 \times 4$ factorial arrangement. The Marandu and BRS Piatã cultivars were evaluated under two water availability conditions, with or without water restriction. The harvests were carried out $0,7,14$ and 28 days after the start of water restriction. For both cultivars, the water deficit stress caused a reduction in shoot biomass and leaf area and an increase in the percentage of roots in the deeper soil layers. The B. brizantha cv. Marandu reached critical levels of leaf water potential in a shorter period of water restriction than did the B. brizantha cv. BRS Piatã. The osmoregulation and deepening of the root system are mechanisms of adaptation to water stress observed in both Marandu and BRS Piatã cultivars. Besides that, the Marandu cultivar also increases its leaf senescence and, consequentially, decreases its leaf area, as a response to water deficit.
\end{abstract}

Key Words: BRS Piatã, Marandu, osmotic potential, water availability, water potential

\section{Introduction}

In the future, changes in rainfall patterns and atmospheric water demand (IPCC, 2007) will affect the availability of water for human consumption, agriculture and energy generation.

The plant resistance to drought involves anatomical, morphological and physiological characteristics that inhibit dehydration or make plants tolerant to dehydration (Taiz \& Zeiger, 2010). Among the mechanisms observed in various species are: decrease in leaf area through a decrease in the leaf expansion rate, an increase in the senescence rate or a decrease in the number of leaves and tillers; deepening of the root system; stomatal closure; osmoregulation by accumulating solutes such as carbohydrates, organic acids, amino acids and inorganic ions; deposition of wax on the leaf epidermis; adaptations in size, anatomy and arrangement of leaves; changes in the cell membrane structure; and alteration in enzyme activity and genetic expression (Rai, 2002; Ramanjulu \& Bartels, 2002; Mahajan \& Tuteja, 2005; Reynolds et al., 2005).

The Brachiaria genus contains around 97 species, native to the Americas, Australia, Southeast Asia and Africa. These species have wide morphological and phenological diversity and their taxonomic limits are still not well defined. The species of this genus grow in a wide range of habitats, such as savannas, flooded or desert regions, under direct sunlight or shade (Buxton \& Fales, 1994; KellerGrein et al., 1996).

Knowledge of the physiological response mechanisms of plants to abiotic stress conditions can help develop improved varieties and selection of new cultivars that are better adapted to particular environmental conditions (Ramanjulu \& Bartels, 2002; Ishitani et al., 2004). The development of forage grass cultivars that are more resistant to water deficit and more efficient water users is one of the alternatives to adapt animal production systems to global climate changes.

Brachiaria brizantha (Hochst ex. A. Rich) Stapf. (Syn. Urochloa) is used for forage production in Brazil. This species is native to Tropical Africa, with accessions that have been collected in areas with average annual rainfall varying from 590 to $2,770 \mathrm{~mm}$ and with dry periods ranging from 0 to 7 months (Keller-Grein et al., 1996).

The objectives of this study were to compare two Brachiaria brizantha cultivars with extreme behaviors regarding adaptation to water deficit and to determine the response mechanisms of these genotypes to stress. 


\section{Material and Methods}

The experiment was conducted in a greenhouse at the EMBRAPA Southeast Livestock, located in São Carlos, São Paulo State, Brazil, from December 2008 to March 2009. The two cultivars were chosen based on preliminary experiments in which Brachiaria brizantha cv. BRS Piatã and Brachiaria brizantha $\mathrm{cv}$. Marandu showed contrasting responses to water restriction.

The conditions inside the greenhouse were monitored daily by an electronic humidity and temperature meter (Instrutemp model HT-3000) and a Piche evaporimeter. Daily maximum, minimum and mean temperatures during the experiment were on average 32,18 and $25^{\circ} \mathrm{C}$. Average relative humidity was $87 \%$ and cumulative evaporation during the 28-day-long experiment was $80 \mathrm{~mm}$.

The experimental design was in completely randomized blocks with a $2 \times 2 \times 4$ factorial arrangement (two cultivars, two water conditions and four harvesting periods) with three replicates. The Marandu and BRS Piatã cultivars were evaluated under two water availability conditions, with or without water restriction, the first one referred to as the stress condition and the second as the control. The harvests were carried out $0,7,14$ and 28 days after the start of water restriction.

The genotypes were planted in 48 pots measuring $0.6 \mathrm{~m}$ in depth and $25 \mathrm{~cm}$ in diameter, made from PVC tubes. The pots were filled with fine air-dried earth with the following chemical and physical characteristics: $\mathrm{pH}_{\mathrm{CaCl}} 4.0$; organic matter $17 \mathrm{~g} \mathrm{dm}^{-3} ; \mathrm{P}_{\text {resin }} 4 \mathrm{mg} \mathrm{dm}^{-3} ; \mathrm{SO}_{4}-\mathrm{S} 12 \mathrm{mg} \mathrm{dm}^{-3}$; K 0.8 mmolc dm ${ }^{-3}$; Ca 7 mmolc dm ${ }^{-3}$; $\mathrm{Mg} 3 \mathrm{mmolc} \mathrm{dm}^{-3}$; $\mathrm{H}+\mathrm{Al} 43 \mathrm{mmolc} \mathrm{dm}^{-3}$; Al 5 mmolc dm ${ }^{-3}$; cation-exchange capacity $54 \mathrm{mmolc} \mathrm{dm}^{-3}$; base saturation $20 \%$; boron $0.18 \mathrm{mg} \mathrm{dm}^{-3} ; \mathrm{Cu} 0.8 \mathrm{mg} \mathrm{dm}^{-3} ; \mathrm{Fe} 40 \mathrm{mg} \mathrm{dm}^{-3} ; \mathrm{Mn} 4.2 \mathrm{mg} \mathrm{dm}^{-3}$; Zn $0.4 \mathrm{mg} \mathrm{dm}^{-3}$; sand $710 \mathrm{~g} \mathrm{~kg}^{-1}$; silt $48 \mathrm{~g} \mathrm{~kg}^{-1}$; and clay $242 \mathrm{~g} \mathrm{~kg}^{-1}$. Before the soil was placed in the pots, its $\mathrm{pH}$ was corrected with $29 \mathrm{~g}$ lime per pot. Twenty seeds were planted in each pot one month after liming. At the time of sowing, $0.50 \mathrm{~g}$ of $\mathrm{P}_{2} \mathrm{O}_{5}$ per pot was applied. After germination, the plants were thinned, leaving three plants per pot.

After sowing, all the pots were kept at field capacity until the experiment began. Three weeks after planting, at the beginning of tillering, the plants were fertilized with $0.25 \mathrm{~g} \mathrm{~N}$ per pot. Eight weeks after planting, the plants were cut to a $20-\mathrm{cm}$ height and the same amount of nitrogen fertilizer was applied ( $0.25 \mathrm{~g} \mathrm{~N}$ per pot). The experiment began 25 days after cutting, when the irrigation of pots from the deficit-treatment was interrupted. The pots in the control group (without water restriction) continued to be irrigated to field capacity until the end of the experiment.

The following variables were analyzed: leaf water potential (MPa), leaf osmotic potential (MPa), dry mass of leaf blades (mg per plant), stems (stems and pseudostems; mg per plant), dead material (mg per plant) and roots ( $\mathrm{mg}$ per plant), leaf area $\left(\mathrm{cm}^{2}\right)$ and soil moisture (\%). Percentage of leaves, stems, dead material and roots in total plant dry mass were calculated.

The water potential and osmotic potential were determined 6, 13, 20 and 27 days after the start of water restriction. To determine the water potential, leaf disks measuring $25 \mathrm{~mm}$ in diameter were collected from the newest fully expanded leaf of one plant per pot, between $10 \mathrm{~h} 00$ and $14 \mathrm{~h} 00$ and immediately placed in psychometric chambers (Wescor model C52). The water potential of the leaf disks was evaluated with the aid of a micro-voltmeter (Wescor, Psypro model).

The osmotic potential was determined from an extract from the same portion of the leaves used to determine the water potential, collected on filter paper using a press (Wescor Markhart Leaf Press, model LP-27). Then the filter paper was placed in the psychrometer for measurement of the osmotic potential (Taiz \& Zeiger, 2010).

At each harvest time $(0,7,14$ and 28 days after the start of water restriction), the shoot was cut, separated into leaf blades, stem + pseudostem and dead material and each portion was weighed. The leaf area was measured using a leaf area meter (LI-COR model LI-3100C). The soil inside the PVC pots was sectioned into the following zones: 0 to $20 \mathrm{~cm}, 21$ to $40 \mathrm{~cm}$ and 41 to $60 \mathrm{~cm}$. After removing a sample from each soil section for moisture determination, the section was washed in running water while held in a $1-\mathrm{mm}$ mesh sieve to separate the roots. The dry mass of the leaf blades, stems + pseudostems, dead material and roots was determined after oven-drying at $65^{\circ} \mathrm{C}$. The soil moisture was measured 7,14 and 28 days after the start of water restriction by the gravimetric method after oven-drying at $105{ }^{\circ} \mathrm{C}$, for a period of approximately 30 hours. Because the irrigation of the pots was suspended from the first cutting, the soil moisture was not evaluated at this time.

The data were subjected to analysis of variance by the GLM procedure of the SAS program (Statistical Analysis System, version 9.2), considering the effects of block, cultivar and water treatment at the time of sampling and their respective interactions as sources of variation. The Tukey test was used for multiple comparisons of the means, at the level of $5 \%$ of significance. 


\section{Results}

Harvest time $(\mathrm{P}<0.0001)$, cultivar $(\mathrm{P}<0.01)$, treatment $(\mathrm{P}<0.0001)$ and interaction of harvest time and treatment $(\mathrm{P}<0.0001)$ had a significant effect on the soil moisture in the three layers evaluated. The soil moisture at the depths of 0 to $20 \mathrm{~cm}, 21$ to $40 \mathrm{~cm}$ and 41 to $60 \mathrm{~cm}$ was lower in the water-deficit treatment for harvests at 7, 14 and 28 days after the start of water restriction (Table 1). From the second to the fourth harvest, the soil moisture only declined in the water-deficit treatment (Table 1).

The soil moisture was lower for Marandu (15.1, 17.9 and $24.4 \%$ in the layers of 0 to 20,21 to 40 and 41 to $60 \mathrm{~cm}$, respectively) than for the BRS Piatã cultivar (16.2, 20.1 and $27.6 \%$ in the layers from 0 to 20,21 to 40 and 41 to $60 \mathrm{~cm}$, respectively). The lower moisture in the pots cultivated with the Marandu cultivar indicates greater water extraction by this cultivar.

The dry mass of the entire plant was higher for Marandu ( $\mathrm{P}<0.0001 ; 29.5 \pm 1.3$ g per plant) than for BRS Piatã (20.6 $\pm 1.1 \mathrm{~g}$ per plant) and increased over harvest time ( $\mathrm{P}<0.05$; from $22.4 \pm 1.7$ to $28.7 \pm 2.4$ g per plant from the first to the last harvest). The dry mass of the shoots, stems and leaves was influenced by the interaction between the harvest and moisture condition $(\mathrm{P}<0.05)$; for the three variables, the effect of water stress was observed starting 14 days after the start of water restriction (Table 2). The dry mass of the shoots and stems increased as the harvest date progressed only in the control group (Table 2). There was no significant effect of the harvest date on the leaf dry mass under either of the moisture conditions (Table 2).

The interaction of cultivar, harvest time and moisture condition was significant for the dry mass of the dead material $(\mathrm{P}<0.01)$. For the BRS Piatã cultivar there was no effect of the moisture condition on the dead material mass (Figure 1). For the Marandu cultivar the dead material mass was greater in the treatment with stress in the last harvest than in the other treatments (Figure 1).

The root dry mass was greater $(\mathrm{P}<0.0001)$ for Marandu $(8.6 \pm 0.5 ; 3.3 \pm 0.2 ; 3.0 \pm 0.2 \mathrm{~g}$ per plant in the layers from 0 to 20,21 to 40 and 41 to $60 \mathrm{~cm}$ layers, respectively) compared with the BRS Piatã cultivar $(4.8 \pm 0.3 ; 1.6 \pm 0.1 ; 1.2 \pm 0.2 \mathrm{~g}$

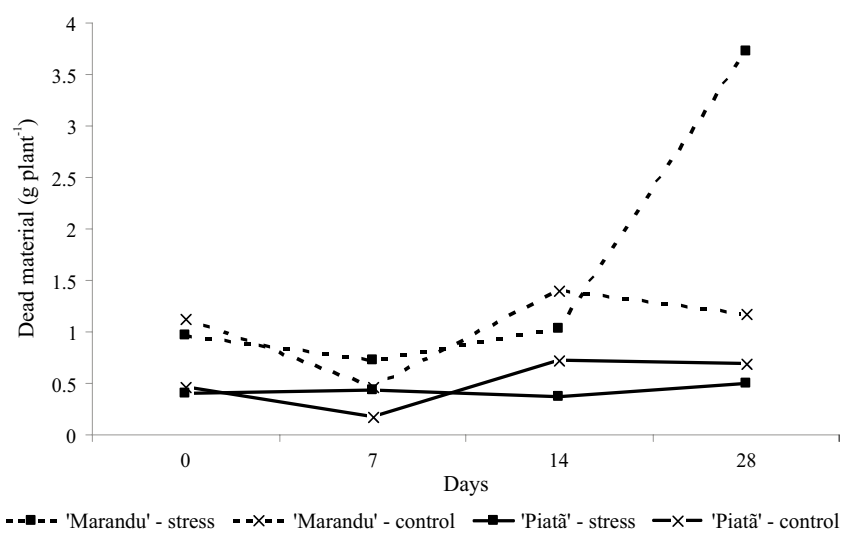

Figure 1 - Dead material mass of Marandu and BRS Piatã cultivars over four harvest dates $(0,7,14$ and 28 days after the start of water restriction) with and without water stress.

Table 1 - Gravimetric soil moisture in the different layers of pots cultivated with two Brachiaria brizantha cultivars at three harvest times with (S) and without water stress (control - C)

\begin{tabular}{|c|c|c|c|c|c|c|}
\hline \multirow{3}{*}{ Day $^{1}$} & \multicolumn{6}{|c|}{ Gravimetric soil moisture $(\%)^{2}$} \\
\hline & \multicolumn{2}{|c|}{0 to $20 \mathrm{~cm}$} & \multicolumn{2}{|c|}{21 to $40 \mathrm{~cm}$} & \multicolumn{2}{|c|}{41 to $60 \mathrm{~cm}$} \\
\hline & $\mathrm{S}$ & $\mathrm{C}$ & $\mathrm{S}$ & $\mathrm{C}$ & $\mathrm{S}$ & $\mathrm{C}$ \\
\hline 7 & $15.0 \pm 0.7 \mathrm{Ab}$ & $19.9 \pm 0.4 \mathrm{Aa}$ & $19.3 \pm 1.5 \mathrm{Ab}$ & $22.8 \pm 0.9 \mathrm{Aa}$ & $27.2 \pm 2.6 \mathrm{Ab}$ & $33.9 \pm 1.0 \mathrm{Aa}$ \\
\hline 14 & $11.5 \pm 0.7 \mathrm{Bb}$ & $19.0 \pm 0.4 \mathrm{Aa}$ & $16.8 \pm 1.2 \mathrm{Bb}$ & $24.0 \pm 0.7 \mathrm{Aa}$ & $19.5 \pm 2.2 \mathrm{Ab}$ & $34.9 \pm 1.2 \mathrm{Aa}$ \\
\hline 28 & $8.4 \pm 0.3 \mathrm{Cb}$ & $20.0 \pm 0.6 \mathrm{Aa}$ & $9.1 \pm 0.6 \mathrm{Cb}$ & $22.6 \pm 0.4 \mathrm{Aa}$ & $9.2 \pm 0.8 \mathrm{Ab}$ & $31.2 \pm 0.8 \mathrm{Aa}$ \\
\hline
\end{tabular}

${ }^{1}$ Days after the start of water restriction.

2 The values are the means of the two cultivars and three replications \pm standard error of the mean.

Means followed by the same uppercase letters in the column and lowercase letters in the row differ by the Tukey test at $5 \%$.

Table 2 - Dry mass of shoots, leaves and stems of two Brachiaria brizantha cultivars over four harvest dates with (S) and without water stress (control - C)

\begin{tabular}{|c|c|c|c|c|c|c|}
\hline \multirow{2}{*}{ Day $^{1}$} & \multicolumn{2}{|c|}{ Shoots $^{2}$ (g per plant) } & \multicolumn{2}{|c|}{ Leaves $^{2}$ (g per plant) } & \multicolumn{2}{|c|}{ Stems $^{2}$ (g per plant) } \\
\hline & $\mathrm{S}$ & $\mathrm{C}$ & $\mathrm{S}$ & $\mathrm{C}$ & $\mathrm{S}$ & $\mathrm{C}$ \\
\hline 0 & $12.1 \pm 1.0 \mathrm{Aa}$ & $12.7 \pm 0.9 \mathrm{Ba}$ & $4.6 \pm 0.2 \mathrm{Aa}$ & $4.2 \pm 0.2 \mathrm{Aa}$ & $6.9 \pm 0.8 \mathrm{Aa}$ & $7.7 \pm 0.5 \mathrm{BCa}$ \\
\hline 7 & $14.0 \pm 1.3 \mathrm{Aa}$ & $12.1 \pm 1.3 \mathrm{Ba}$ & $4.7 \pm 0.4 \mathrm{Aa}$ & $4.4 \pm 0.3 \mathrm{Aa}$ & $8.7 \pm 0.8 \mathrm{Aa}$ & $7.4 \pm 1.0 \mathrm{Ca}$ \\
\hline 14 & $12.0 \pm 0.9 \mathrm{Ab}$ & $16.3 \pm 1.2 \mathrm{Aa}$ & $3.7 \pm 0.3 \mathrm{Ab}$ & $5.3 \pm 0.6 \mathrm{Aa}$ & $7.6 \pm 0.7 \mathrm{Ab}$ & $9.9 \pm 0.9 \mathrm{ABa}$ \\
\hline 28 & $13.9 \pm 1.5 \mathrm{Ab}$ & $17.6 \pm 1.1 \mathrm{Aa}$ & $3.3 \pm 0.4 \mathrm{Ab}$ & $5.2 \pm 0.5 \mathrm{Aa}$ & $8.5 \pm 0.8 \mathrm{Ab}$ & $11.6 \pm 0.6 \mathrm{Aa}$ \\
\hline
\end{tabular}

${ }^{1}$ Days after the start of water restriction.

2 The values are the means of the two cultivars and three replications \pm standard error of the mean.

Means followed by the same uppercase letters in the column and lowercase letters in the row differ by the Tukey test at $5 \%$. 
per plant in the layers from 0 to 20,21 to 40 and 41 to $60 \mathrm{~cm}$, respectively) in all the layers evaluated.

The leaf area was influenced by the interaction of cultivar, harvest time and treatment $(\mathrm{P}<0.05)$. There was no difference between cultivars and treatments in the first three harvest times (Figure 2). For both cultivars, the leaf area of plants from the control treatment was higher compared with the stress treatment in the last harvest. The leaf area of Marandu plants under water restriction was smaller in the last harvest than that of Marandu plants harvested at earlier dates (Figure 2). The leaf area of Marandu plants in the stress group was also lower than that of BRS Piatã plants in the stress group (Figure 2).

The Marandu cultivar $(\mathrm{P}<0.0001 ; 50.2 \pm 0.7 \%)$ had a higher percentage of roots among the total plant dry mass compared with the BRS Piatã cultivar $(36.3 \pm 1.3 \%)$, but there was no effect of the moisture condition or the harvest time on this variable. The BRS Piatã cultivar $(\mathrm{P}<0.01$; $63.6 \pm 1.5 \%)$ had a higher percentage of the root system in the layer from 0 to $20 \mathrm{~cm}$ than the Marandu cultivar $(57.6 \pm 1.4 \%)$. The root system percentage in the layer from 41 to $60 \mathrm{~cm}$, in turn, was higher for the Marandu cultivar

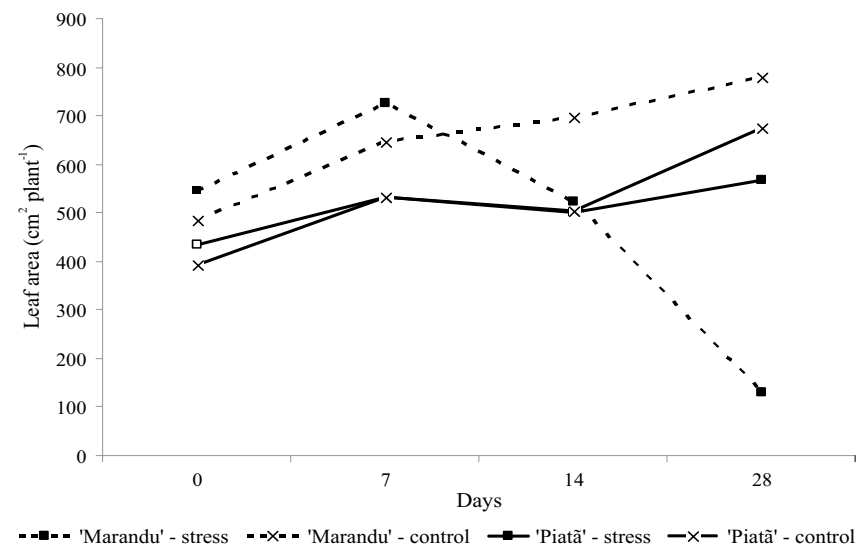

Figure 2 - Leaf area $\left(\mathrm{cm}^{2}\right)$ of Marandu and BRS Piatã cultivars over four harvest dates $(0,7,14$ and 28 days after the start of water restriction) with and without water stress.
$(\mathrm{P}<0.001 ; 20.0 \pm 1.1 \%)$ than for the BRS Piatã cultivar $(15.3 \pm 1.3 \%)$. In the soil layer from 21 to $40 \mathrm{~cm}$ there was no difference between the two cultivars. The percentage of roots in the layer from 41 to $60 \mathrm{~cm}$ was greater for the water deficit treatment $(\mathrm{P}<0.01 ; 19.7 \pm 1.4 \%)$ than for the control group (15.6 $\pm 1.2 \%)$. The percentage of leaves in the shoots declined with later harvest times $(\mathrm{P}<0.0001$; from $35.7 \pm 1.4 \%$ to $27.0 \pm 2.0 \%$ from the first to the last harvest) and was smaller in the Marandu cultivar $(\mathrm{P}<0.01$; $30.4 \pm 1.5 \%)$ than in the BRS Piatã cultivar $(35.0 \pm 1.1 \%)$. The percentage of stems in the shoots was not affected by the treatments. The percentage of dead material, in turn, was affected by the interaction between cultivar, harvest time and moisture condition $(\mathrm{P}<0.0001)$. For the BRS Piatã cultivar there was no effect of moisture condition on the percentage of dead material (Figure 3); however for the Marandu cultivar the percentage of dead material was greater in the water deficit treatment at the last harvest (Figure 3) than at the first three harvests. In the last harvest, the percentage of dead material in Marandu plants from the stress group was also higher compared with BRS Piatã plants from the stress group (Figure 3).

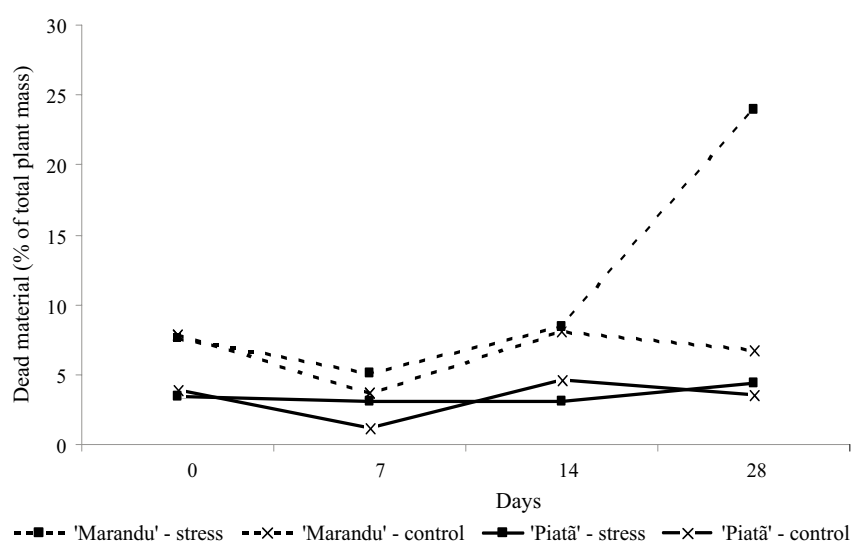

Figure 3 - Percentage of dead material mass of Marandu and BRS Piatã cultivars over four harvest dates $(0,7,14$ and 28 days after the start of water restriction) with and without water stress.

Table 3 - Water potential and osmotic potential of two Brachiaria brizantha cultivars over five harvest dates with (S) and without water stress (control - C)

\begin{tabular}{|c|c|c|c|c|c|c|}
\hline \multirow{2}{*}{ Day $^{1}$} & \multicolumn{2}{|c|}{ WWater $^{2}$} & \multicolumn{2}{|c|}{ YOsmotic $^{2}$} & \multirow{2}{*}{$\mathrm{T}\left({ }^{\circ} \mathrm{C}\right)$} & \multirow{2}{*}{ RH (\%) } \\
\hline & $\mathrm{S}$ & $\mathrm{C}$ & $\mathrm{S}$ & $\mathrm{C}$ & & \\
\hline 0 & - & $-1.37 \pm 0.06$ & - & $-0.55 \pm 0.13$ & 24.7 & 84 \\
\hline 6 & $-1.05 \pm 0.02 \mathrm{Aa}$ & $-1.09 \pm 0.04 \mathrm{Aa}$ & $-0.70 \pm 0.09 \mathrm{Aa}$ & $-0.75 \pm 0.06 \mathrm{Aa}$ & 22.3 & 94 \\
\hline 13 & $-1.46 \pm 0.09 \mathrm{Ba}$ & $-1.52 \pm 0.10 \mathrm{Ba}$ & $-0.62 \pm 0.10 \mathrm{Aa}$ & $-0.81 \pm 0.08 \mathrm{Aa}$ & 24.8 & 80 \\
\hline 20 & $-1.50 \pm 0.20 \mathrm{Bb}$ & $-1.11 \pm 0.04 \mathrm{Aa}$ & $-0.74 \pm 0.1 \mathrm{~A} 6 \mathrm{~b}$ & $-0.65 \pm 0.1 \mathrm{~A} 4 \mathrm{a}$ & 25.0 & 92 \\
\hline 27 & $-2.13 \pm 0.15 \mathrm{Cb}$ & $-1.56 \pm 0.09 \mathrm{Ba}$ & $-1.23 \pm 0.22 \mathrm{Bb}$ & $-0.57 \pm 0.08 \mathrm{Aa}$ & 27.3 & 86 \\
\hline
\end{tabular}

${ }^{1}$ Days after the start of water restriction.

${ }^{2}$ The values are the means of the two cultivars and three repetitions \pm standard error of the mean.

$\mathrm{T}$ - temperature; $\mathrm{RH}$ - relative humidity.

Means followed by the same uppercase letters in the column and lowercase letters in the row differ by the Tukey test at $5 \%$.

The data from the first harvest were not considered in the statistical analysis. 
The Marandu cultivar had lower water potential $(\mathrm{P}<0.05 ;-1.51 \pm 0.09 \mathrm{MPa})$ than BRS Piatã $(-1.34 \pm 0.08$ $\mathrm{MPa})$. The osmotic potential only differed between the two cultivars in the treatment with stress $(\mathrm{P}<0.05 ;-0.98 \pm 0.07$ $\mathrm{MPa}$ and $-0.67 \pm 0.07 \mathrm{MPa}$ for the Marandu and BRS Piatã cultivars under water stress conditions, respectively). In the control group the osmotic potential of the two cultivars was $-0.70 \mathrm{MPa}$.

Both the water potential and osmotic potential were influenced by the interaction of the harvest and moisture condition $(\mathrm{P}<0.01)$. The water potential of the water deficit treatment diminished over the harvests (Table 3), while in the control group it was highest at the second and fourth dates. The water potential of the plants under stress conditions was lower than that of the plants in the control group only at the last two harvests. The osmotic potential was lower at the end of the experiment in the plants under stress conditions, but did not change over time in the plants of the control group. The osmotic potential of the plants grown under stress conditions was lower than that of the control plants only in the last harvest.

\section{Discussion}

The dry mass of the shoots, leaves and stems was lower in the treatment with stress from the third harvest on, but there was no effect of the moisture condition on the root dry mass. Starting with the second harvest, the soil moisture was lower in the treatment with stress in the three soil layers evaluated. At the third and fourth harvest dates, the soil water in the treatment with stress was less than $70 \%$ and $45 \%$ of soil water in the control group, respectively. Guenni et al. (2002) observed a 23\% reduction in the dry mass of Brachiaria brizantha plants as a function of restricted water supply. Melo et al. (2003) noted that the shoot dry mass of Brachiaria brizantha in soil maintained at $60 \%$ of field capacity was about $30 \%$ lower than the plants grown in soil kept at $80 \%$ of field capacity.

In the present study, although the water deficit restricted the growth of the shoots without reducing the development of the root system, there was no significant effect of the moisture condition on the partitioning of the total plant dry mass.

The percentage of roots in the layer from 41 to $60 \mathrm{~cm}$, on the other hand, was greater for the plants grown under water stress conditions. Huang \& Fu (2000) observed greater allocation of recently assimilated carbon to the root system, mainly in the deeper soil layers, in temperate grasses (Poa pratensis and Festuca arundinaceae) subjected to water stress conditions. Deepening of the root system has been described in other experiments about water deficit with species of the Brachiaria genus (Guenni et al., 2002; Guenni et al., 2006).

In this study, most of the root system was concentrated in the 0 to $40 \mathrm{~cm}$ layer, regardless of the treatment and cultivar. Similar results were obtained by Guenni et al. (2002), who observed a concentration of the root system of Brachiaria brizantha cultivars down to $50 \mathrm{~cm}$ in depth.

The lower moisture in the pots containing the Marandu cultivar indicates greater water extraction by this cultivar. Guenni et al. (2002) observed that the water utilization rate was higher for $B$. brizantha, B. decumbens and B. mutica (0.251 $\mathrm{L} \mathrm{day}^{-1}$ plant $^{-1}$ ) than for B. humidicola (CIAT 679) and $B$. dictyoneura (CIAT 6133) (0.131 L day ${ }^{-1}$ plant $^{-1}$ ). The results of the present experiment suggest that besides differences between species, there is also variation in the water utilization rate between cultivars of Brachiaria brizantha.

Differences in water extraction between Brachiaria brizantha cultivar may be related to root system development. The Marandu cultivar produced greater dry mass of the entire plant and roots and showed a higher percentage of dry matter in the roots than the BRS Piatã cultivar. The root system of Marandu also had a higher percentage of roots in the deepest soil layer, better exploiting that profile to absorb water.

Most of the water extracted by plants from the soil is lost by transpiration. Decreasing leaf area and closing of the stomata are some of the mechanisms employed by plants to reduce water consumption and balance their water relations under conditions of water stress.

In the present experiment, leaf area did not differ between cultivars, except in the last harvest, when leaf area of Marandu plants from the stress group was lower than that of BRS Piatã plants. Although differences in leaf area were not significant, the tendency of Marandu plants to have a higher leaf area than Piatã plants at the beginning of the experiment may have influenced water-extraction of both cultivars.

At the last harvest there was an increase in the dry mass of dead tissue and percentage of dead material in the Marandu cultivar under stress. Although the senescence rate was not evaluated, the increase in dry mass and percentage of dead material showed that this was an important mechanism to reduce the leaf area of Marandu cultivar under water stress. This characteristic should be evaluated in new experiments.

Stomata closure also reduces the $\mathrm{CO}_{2}$ exchanges and interferes with photosynthesis rate and production potential of plants. Anyia \& Herzog (2004) reported a reduction in water use and biomass production of cowpea plants (Vigna unguiculata) due to water deficit 
and attributed this reduction in biomass to the decline in gas exchange and leaf area during the stress period. The correlation between stomatal conductance and net photosynthesis in genotypes of Brachiaria brizantha has been reported in several studies (Dias-Filho \& Carvalho, 2000; Dias-Filho, 2002).

Milbau et al. (2005) observed that species in which the stomatal conductance and photosynthesis rate are related to the relative water content of the soil survive for longer periods of severe water shortage than those whose stomatal conductance and photosynthesis rate respond more to daily fluctuations of sunlight, temperature and vapor pressure deficit. The authors suggested that the differences between species with respect to tolerance for extreme water stress conditions are related to the degree of response of the stomata to soil moisture conditions. The lower yield of BRS Piatã cultivar and its greater soil moisture suggests that the gas exchange control by stomatal closure may be one of the mechanisms for adaptation to the water deficit stress developed by this cultivar. This hypothesis was not tested in this experiment and should be analyzed in future studies.

The water potential of the plants in the control group reflected the variations in temperature and relative air humidity on the day of evaluation, varying from -1.09 to $-1.56 \mathrm{MPa}$. In the second and fourth harvests, when the water potential of the control group was highest, the relative air humidity was higher than in the other harvests. Besides that, in the second harvest, the temperature was lower than in the other harvest. Guenni et al. (2004) noted water potential values lower than $-0.5 \mathrm{MPa}$ in well watered Brachiaria brizantha plants. The authors evaluated the water potential just before dawn, which explains the higher levels than in the present experiment (water potential was measured between $10 \mathrm{~h} 00$ and 14h00).

The plants under stress conditions had a water potential of $-2.13 \mathrm{MPa}$ at the last harvest. Guenni et al. (2006) determined that the critical water potential value, associated with a sharp reduction in the stomatal conductance and photosynthesis, was in the range of -2.0 to -5.0 for the Brachiaria species.

The osmotic potential of Marandu was lower than that of BRS Piatã in the water deficit treatment, mainly due to the reduction at the last harvest. The decline in the osmotic potential of the Marandu cultivar leaves reflects, in part, the lower water availability in this treatment. Guenni et al. (2004) observed differences between Brachiaria species regarding the time necessary for water stress symptoms to appear after interrupting irrigation and attributed these differences to variations in the speed of water extraction from the soil between genetic varieties. Osmotic adjustment is one of the mechanisms to adapt to water deficit stress developed by plants. The reduction of the water potential by osmotic adjustment enables the absorption of water from soils with lower water availability.

\section{Conclusions}

Osmoregulation and deepening of the root system are mechanisms of adaptation to water stress observed in both Marandu and BRS Piatã cultivars. Besides that, the Marandu cultivar also increases its leaf senescence and, consequentially, decreases its leaf area, as a response to water deficit.

\section{References}

ANYIA, A.O.; HERZOG, H. Water-use efficiency, leaf area and leaf gas exchange of cowpeas under mid-season drought. European Journal of Agronomy, v.20, p.327-339, 2004.

BUXTON, T.R.; FALES, S.L. Plant environment and quality. In: FAHEY JUNIOR, G.C. (Ed.) Forage quality, evaluation and utilization. Madison: American Society of Agronomy, 1994. p.155-199.

DIAS-FILHO, M.B. Tolerance to flooding in five Brachiaria brizantha accessions. Pesquisa Agropecuária Brasileira, v.37, n.4, p.439-447, 2002.

DIAS-FILHO, M.B.; CARVALHO, C.J.R. Physiological and morphological responses of Brachiaria spp. to flooding. Pesquisa Agropecuária Brasileira, v.35, n.10, p.1959-1966, 2000.

GUENNI, O.; BARUCH, Z.; MARÍN, D. Responses to drought of five Brachiaria species. II. Water relations and leaf gas exchange. Plant and Soil, v.258, p.249-260, 2004.

GUENNI, O.; GIL, J.L.; BARUCH, Z. et al. Respuestas al déficit hídrico em espécies forrajeras de Brachiaria (Trin.) Griseb. (Poaceae). Interciencia, v.31, n.7, p.505-511, 2006.

GUENNI, O.; MARÍN, D.; BARUCH, Z. Responses to drought of five Brachiaria species. I. Biomass production, leaf growth, root distribution, water use and forage quality. Plant and Soil, v.243, p.229-241, 2002.

HUANG, B.; FU, J. Photosynthesis, respiration, and carbon allocation of two cool-season perennial grasses in response to surface soil drying. Plant and Soil, v.227, p.17-26, 2000.

IPCC. Intergovernmental Panel on Climate Change - 4th Assessment Report. 2007. Available at: <http://www.ipcc.ch/>. Accessed on: Feb. 1, 2010.

ISHITANI, M.; RAO, I.; WENZL, P. et al. Integration of genomics approach with traditional breeding towards improving abiotic stress adaptation: drought and aluminum toxicity as case studies. Field Crops Research, v.90, p.35-45, 2004.

KELLER-GREIN, G.; MAASS, B.L.; HADSON, J. Natural variation in Brachiaria and existing germoplasm collections. In: MILES, J.W.; MAAS, B.L.; VALLE, C.B. (Eds.) Brachiaria: Biology, agronomy, and improvement. Cali: CIAT; Brasília: EmbrapaCNPGC, 1996. p.106-123.

MAHAJAN, S.; TUTEJA, N. Cold, salinity and drought stresses: An overview. Archives of Biochemistry and Biophysics, v.444, p.139-158, 2005.

MELO, S.P.; KORNDÖRFER, G.H.; KORNDÖRFER, C.M. et al. Silicon accumulation and water deficit tolerance in Brachiaria garsses. Scientia Agricola, v.60, n.4, p.755-759, 2003.

MILBAU, A.; SCHEERLINCK, L.; REHEUL, D. et al. Ecophysiological and morphological parameters related to survival in grass species exposed to an extreme climatic event. Physiologia Plantarum, v.125, p.500-512, 2005. 
RAI, V.K. Role of amino acids in plant responses to stresses. Biologia Plantarum, v.45, p.481-487, 2002.

RAMANJULU, S.; BARTELS, D. Drought- and desiccationinduced modulation of gene expression in plants. Plant, Cell and Environment, v.25, p.141-151, 2002.
REYNOLDS, M.P.; MUJEEB-KAZI, A.; SAWKINS, M. Prospects for utilising plant-adaptive mechanisms to improve wheat and other crops in drought- and salinity-prone environments. Annals of Applied Biology, v.146, p.239-259, 2005.

TAIZ, L.; ZEIGER, E. Plant physiology. 5.ed. Sunderland: Sunauer Associates, 2010. 782p. 